\title{
Beaded shoes: the culture of Baba Nyonya
}

\author{
Noor Azam Azmi ${ }^{1}$, Amirul Nizam ${ }^{2}$, Diana Mohamad $^{3} \&$ Badaruddin Mohamed ${ }^{4}$ \\ ${ }^{1234}$ School of Housing, Building and Planning, Universiti Sains Malaysia
}

\begin{abstract}
Despite the rapid changes in shoes' arts and designs due to globalization of cultures and customs, beaded shoes of Baba and Nyonya (else addressed as Baba Nyonya) remain in demand locally and globally. Baba Nyonya is one of the unique tribe or community in Malaysia because of their practiced lifestyle that harmonically combine both Malay and Chinese cultures. This paper descriptively discussed the basic procedure of making beaded shoes which include the philosophy and variations that still exist nowadays, in addition to discussing the technique applied when making beaded shoes. The paper also discussed about how the heritage of arts is still being applied by new generations these days where this is in parallel with the old quotes 'the time might not demolish the heritage arts'. The method employed by the researcher include revisiting literature regarding to the beaded shoes introduced by Baba Nyonya community. To earn a depth and detail information regarding to the beaded shoes, an interview was held with the informant which is one of the motivator or advisor that still practices the heritage arts of Baba Nyonya beaded shoes. The responsibility of continuing the culture is deemed vital and important so the new generation will appreciate and practice the culture practiced by Baba Nyonya.
\end{abstract}

\section{Introduction}

Originating from China, the Baba Nyonya ethnic group or else known as the Straits-born Chinese are the descendants of the Chinese merchants who came to the Malay Archipelago during the 15 th and $16^{\text {th }}$ centuries. As these merchants settled and began families through mix-marriage, the Malay archipelago has become a melting pot for the uniquely blended community. In Malaysia, this exclusive and eminent ethnic can be found in two states namely Malacca and Penang Island (Worden, 2003), where the reside area was chosen due to commerce purpose. The Baba Nyonya, which practicing the distinctive lifestyle that combines both Malay and Chinese culture, is mostly living in Melaka (Lee, 2008). Nowadays, most Baba Nyonya exercised beliefs systems including Taoism, Confucianism, Buddhism, Christianity and Islam. The uniqueness of Chinese festivals celebrated by Baba Nyonya lies in the fact that Baba and Nyonya adapted Portuguese, Dutch, British, Malay and Indonesian influences in the customs. Other than culture, the individuality of Baba Nyonya could be observed in their traditional food, lifestyle and costume. Beaded shoes are one of it. This study is important because there are so many state treasures that are lost. Without any encouragement and effort to understand the culture of the arts of a nation has led the younger generation to move away from it.

\section{Methodology}

Information was collected through literature review pertaining to Baba Nyonya and beaded shoes, in addition to an interview session with Madam Lim Siew Seng in order to gain a authentic pictures and information regarding the Baba Nyonya's beaded shoes (see Figure 1). Information gained from the informant are applicable for use in improving the research (Marshall,1996). May Lim Siew Seng (aged 70 years old) is an active Beads-cobbler and it was learned that she has already engaged in making beaded shoes for almost 40 years, in addition she is also earnestly training the trainers who aim to be beaded shoes maker. 


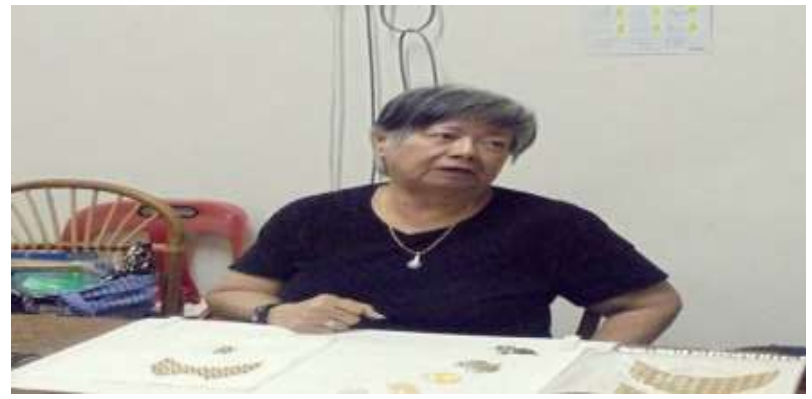

Figure 1. Informant, Madam May Lim Siew Seng

\section{Literature Review}

According to the history, the existence of Straits Chinese or Baba Nyonya ethnicity could be principally dated back to the $15^{\text {th }}$ century $(\mathrm{Khoo}, 1996)$. The history started when the close relationship with China was recognized when the Emperor of China sent his princess (Princess Hang Li Po) to Malacca as a token of gratitude to the Sultan of Malacca. Princess Hang Li Po and her servants decided Bukit Cina as their settlement area and eventually grew into Straitsborn Chinese community. This Straits-born Chinee community known as Peranakans (else known as Baba Nyonya) is a result of mix-marriage between the Chinese and the Malay people. Interestingly, Baba Nyonya relates themselves with the modernism while still retaining the Chinese culture and tradition. To some extent the Chinese culture and tradition are flavoured mainly with the Malay culture and tradition elements and other religions' culture and tradition elements generally (Ahmad Az Mohd Mokhtar, 2012; Han, 2017). As a result of adopting, adapting and practicing various cultures, members of the Baba Nyonya community have mastered three languages: Chinese, Malay and British (Ahmad Az Mohd Mokhtar, 2012).

Currently, the population size of Baba Nyonya living in Melaka is only 600 person; and the population is getting smaller in size. Compunding this alarming fact is the realization that Baba Nyonya unique and eminent traditions and practices are being ignored by the new generations (Utusan Online, 2008). The unique characteristics of this cultures include (1KLIK, 2008; PYZAM, 2010):

1. Descended from China but were loyal to Britain.

2. Speak in Baba dialect where the dialect is Hokkien mixed with Malay languages.

3. Eat food with hand and all the recipes follow the Malys cokking style like using chili, belacan (blended small prawns), galangal acid and lemongrass.

4. The Nyonya (ladies) wear 'kebaya' and 'kain sarung'.

5. Houses are built following the Chinese traditional architecture style.

6. The Baba Nyonya wedding ceremony combines Chinese costumes (Figure 3) and Malays' traditional music (which is sung in Malay).

7. Cultural performance include Lion Dance, Fu Kien Opera and the Dondang Sayang Baba Nyonya.

Other than the aforementioned culture, the uniqueness of Baba Nyonya culture can be seen through the arts of embroidery, kebaya Nyonya, beaded shoes and crafts . Beaded shoes or else known as 'Kasut Manik' are handmade slippers with distinctive pattern created using embroided beads, and the shoes are usually made by the highly skilled artisan. However this highly skilled art are only limitedly inherited by the community in Baba Nyonya (Malaysia Aktif, 2016). The arts of making beaded shoes normally pass to the next generations in the family through family business (Utusan Online, 2008) and learning through observation (Sinar Harian, 2014).

The creation of beaded shoes (either using high quality fine beads or high quality rough beads) normally apply the flower motifs from Europe and high level of patience are needed during the production of the beaded shoes (Ahmad Az Mohd Mokhtar, 2012). In his blog entitled 'Transcrip of Kasut Manik Baba Nyonya', Milo Yahya (2012) stated 
that 'beads used on the shoes are made and imported from Europe, however, due to the high cost, later the beads used are imported from Japan. Despite the low cost, the Japan beads is of better quality and more oriental'. Baba Nyonya traditional beaded shoes motives consist of flora and fauna, and what makes these beaded shoes invaluable, is the fact that the motifs which has been used for a particular pair will not be used for other beaded shoes. The same motifs will be created only when it is requested by the same buyer.

According to WaiHaik Shoemaker which operates-in Melaka, beaded shoes is inhigh demand during the festives seasons. Other than the locals, these beaded shoes have successfully attracted buyers from Japan, Singapore and Germany. The process of making beaded shoes is as follows (Utusan Online, 22 Mei 2010 Accessed on 9 January 2017).

Requested motif is first drawn on the locating device with $1.5 \mathrm{ft} \times 1.5 \mathrm{ft}$ measurement.

1. The beads are then sewed on the motif. Beaded shoes made with high quality fine beads will take approximately three to four months to complete (Grade 1 shoes will incur a cost upwards from RM1000 and Grade 2 will range between RM600 to RM900). Beaded shoes made with high quality rough beads will take approximately two months for completion and the prize ranged between from RM300 to RM450.

2. The completed sewn motifs will be cut accordingly and then, will be stamped on the footwear.

\section{Informant Information}

Beaded shoes are known as 'kasut manik bermuka' or 'face beaded shoes'. Usually and traditionally, the Baba Nyonya will wear beaded shoes when attending formal occasion (for example wedding ceremony) and when visiting family and friends during festive season. Given the nature of occasion of which beaded shoes are worn, the beaded shoes are extraordinarily designed and beautifully decorated. The quality of handsewn/handmade beaded shoes are of better quality compares to machine-sewn beaded shoes. Of importance, the quality of handsewn/handmade beaded shoes is instinctively controlled given the limitation of possibly created designs within a certain period of time. Further, any design or motives are limited to two or three pairs of beaded shoes. Hence, the authenticity value is preserved and maintained.

\subsection{Philosophy of beaded shoes}

Flora and fauna motifs are highly important in the creation of Baba Nyonya beaded shoes. Rose, natural flower and Teluki flowers are the few types of flower motifs used for the design (figure 2); while motives for fauna include birds, lion, dragon and chicken. According to the tradition and as one of the philosophy, the Nyonya (ladies) must wear matching color of beaded shoes and costume. 


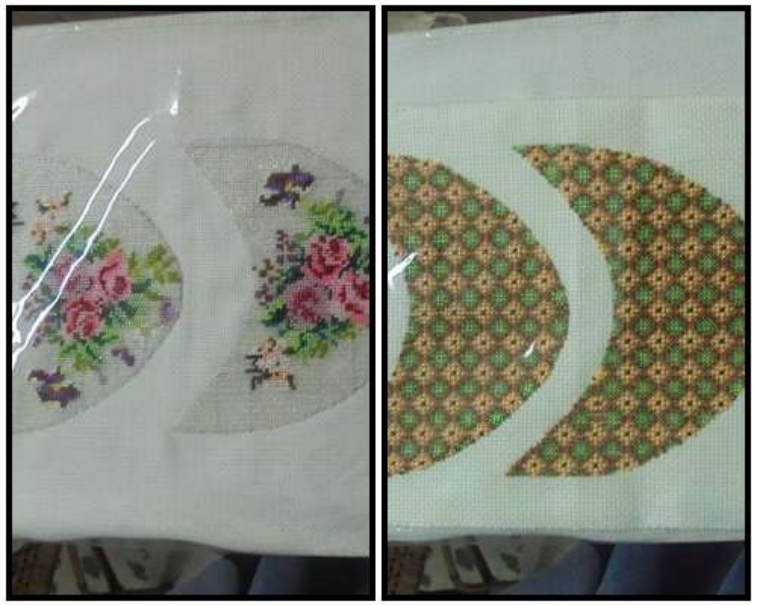

Figure 2. Beaded shoes motifs

\subsection{Variation of beaded shoes today}

To date, despite the fact that beaded shoes are expensive, they are still much in demand due to the authentic design as well as the difficulty of the making process . According to the informant, there are two different variation of beaded shoes, namely the traditional beaded shoes and the modern beaded shoes. Traditional beaded shoes are shoes that still maintain the flora and fauna motif. The material (beads) are imported from Europe because the quality is better and long lasting. Besides the quality aspect, the utilization of European beads emphasizes the distinction between social classes. Hence, indirectly, this indicates subject-positioning. Given these qualities, the traditional beaded shoes are sold at a notably higher price compared to the modern beaded shoes. The usage of traditional beaded shoes are limited to certain occasion or event for example wedding ceremony.

On the other hand, the beads used for the modern beaded shoes are imported from Japan and China. It is said that the beads from Japan are of better quality and the designs are more oriental-based when compared to the beads from China, which are slightly inexpensive. Therefore, modern beaded shoes made using the China beads are sold at a slightly cheaper price compared to modern beaded shoes made using the Japanese beads. In comparison to traditional beaded shoes, the designs for modern beaded shoes are more contemporary. What is meant by contemporary in terms of materials and pattern of use. The design is more modern with a more abstract and geometric pattern. Besides designed with heels, the modern beaded shoes also use pearls and crystal for decoration purpose. The reason for attaching pearls and crystal is to enhance the beads appearance (figure 3 ). 


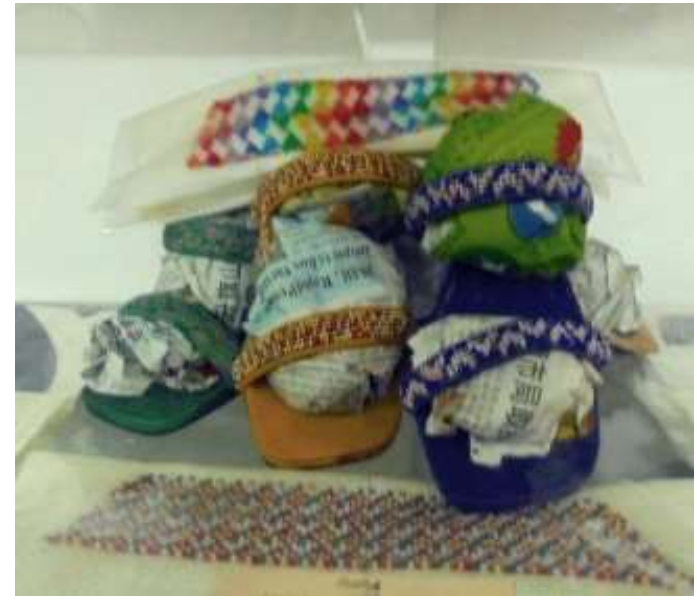

Figure 3. Modern beaded shoes

\subsection{Technique applied in making beaded shoes}

The following technique/procedure is applied when making both traditional and modern beaded shoes. As mentioned by the informant, the technique/procedure will take approximately 3 to 52 weeks to be completed, depending on the design (traditional or modern) and the materials used. This technique/procedure consists of 5 stages, namely:

Stage 1: Preparation of frame and silk cotton

The first step involves the preparation of the location device which measured half feet for both length and width. After the silk cotton is securely attached to the location device, the process of sketching the design will take place.

Stage 2: Sewing the separator or border between beads

Beads are sewed only on the separator/border sketch. This step needs to be completed before moving to the next stage.

Stage 3: Inner beads sewing

At this stage, the thread of complete sewn beads which located at the front of silk cotton will be ended and neatly tied at the back of the cotton. More importantly, this stage tests the credibility of the beaded shoes maker in producing an impressively attractive design. The maker, other than responsible of producing a high quality product, is also challenged in constructing a design that is beyond the expectation of the buyer. This is to maintain the authenticity value of the beaded shoes.

Stage 4: Preparation for footwear base

The footwear base, which normally made from 'Fomika Soo' type leather, will be drawn exactly following the customer foot size. The base will be cut in accordance to the sketches.

Stage 5: Patching the sewing

This stage requires the beaded shoes maker to patch the readily sewn beads to the footwear base. The patching process is done using glu (preferably strong) and after the completion of this process, a specific hammer will be used to neatly levelled the footwear base.

\section{Knowledge transfer}

The informant stated the reason why she is still actively engaging in this industry:is because she wants to share the precious art of making beaded shoes to new generations who appreciates and understands the significance of beaded 
shoes. Classes and workshops organized by the informant have attracted participation from young locals and foreigners. Rather than instructing the trainees to follow the original ideas/designs, the informant has encouraged the trainees to further improvise the existing designs without compromising the meaning of Baba Nyonya culture and customs. Given the fact that the production of beaded shoes involves such a tedious process, it is undeniable that patience and industry are two of many other attributes needed to survive in this industry. Besides classes and workshops, the informant is also involved in the 'Program Pembelajaran Pertukangan Seni Tradisional', which is organized by the Penang Apprenticeship Programme for Artisans (PAPA) (Figure 4). PAPA's mission is ensuring the transfer of the traditional arts knowledge to the new generations. In addition to that, PAPA also invited the informant on overseas trips for the purpose of introducing the Baba Nyonya beaded shoes along with other products created by the artisans.

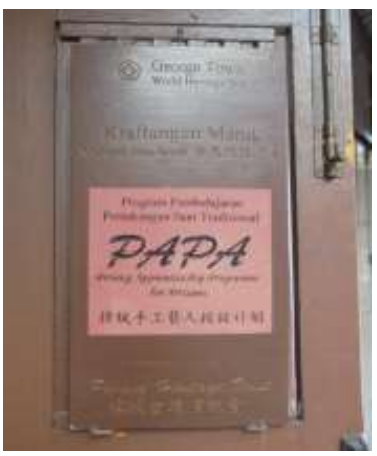

Figure 4. PAPA ;Skills and knowledge transfer program

\section{Conclusion}

The traditional procedure of beaded shoes making should be kept alive as this is significant in ensuring the sustainability of a certain culture in the rapidly transforming modern world. It has been proven that handsewn/handmade beaded shoes are of better quality, long lasting and display origin characteristic. Even though through modernization a lot of high technology equipments have been introduced, these equipments are still inferior to the human touch in terms of highlighting the purity and the authenticity of a product. Even the world value has changed, and the new generations are offered with ranges of products to choose from; sustainability of traditions and customs has to assured. This will help in preserving ones' identity and perception toward arts and culture. Therefore, it is important for the local knowledge of old generation to instill, to teach and to remind the new generations about the importance and the significance of beaded shoes culture and arts. Traditional arts and knowledge transfer program should be paid attention by the appointed organizations such as Penang Island, Penang Apprenticeship Programme for Artisans (PAPA).

\section{Aknowledgement}

The authors would like to extend the aprreciation to Kementerian Pengajian Tinggi Malaysia for the funding of Geran Penyelidikan Jangka Panjang (LRGS), (Kearifan Tempatan), account number 203/PTS/6727002 entitled Contemporizing Trandisiplinary Knowledge Transfer for the assurance of the research and the article. The authors also would like to thank the informant, Madam May Lim Siew Seng, for her great cooperation and valuable information.

\section{References}

1. 1KLIK (2008). Keunikan masyarakat Baba dan Nyonya. Diakses pada 9 Januari 2017 dari http://pmr.penerangan.gov.my/index.php/budaya/8718-keunikan-masyarakat-baba-dan-nyonya.html

2. Ahmad Az Mohd Mokhtar (2012). Kajian mengenai etnik Baba dan Nyonya dan hubungannya dengan rumpun Bahasa Melayu. Diakses pada 9 Januari 2017 dari http://sayauncleaz.blogspot.my/2012/11/etnikbaba-dan-nyonya.html 
3. CRIonline (2016). Pameran kraf tangan Baba dan Nyonya di Singapura. Diakses pada 9 Januari 2017 dari http://malay.cri.cn/901/2016/06/24/241s163289.htm

4. Han (2017). Asal usul Baba dan Nyonya. Diakses pada 9 Januari 2017 dari https://www.academia.edu/8526027/Asal Usul Baba Dan Nyonya?auto=download

5. HardwareZone Malaysia (2016). 59 things that makes us Malaysians. Diakses pada 9 Januari 2017 dari http://www.hardwarezone.com.my/feature-hardwaremerdeka-59-things-makes-usmalaysians/hardwaremerdeka-59-things-makes-us-malaysians-habits-festivals-and-ethnic-costumes

6. Khoo, J. E. (1996). The Straits Chinese: a cultural history. Knickerbocker Press.

7. Lee, S. K. (2008). The Peranakan Baba Nyonya Culture: Resurgence or Disappearance?. SARI: Jurnal Alam dan Tamadun Melayu, 26, 161-170.

8. Malaysia Aktif (2016). Usahawan tunggal Melayu Kasut Manik Baba Nyonya. Diakses pada 9 Januari 2017 dari http://malaysiaaktif.my/malaysiaaktif2/?p=20870

9. Milo Yahya (2012). Transcript of Kasut Manik Baba Nyonya. Diakses pada 9 Januari 2017 dari https://prezi.com/dsu0gcjp8hax/kasut-manik-baba-nyonya/

10. Marshall, M. N. (1996). The key informant technique. Family practice, 13(1), 92-97.

11. Nazrulhad Hashim (2011). Festival antarabangsa Baba dan Nyonya. Diakses pada 9 Januari 2017 dari https://nazrulhad.wordpress.com/2011/12/20/festival-antarabangsa-baba-dan-nyonya/

12. Noraziah Hanafi (2012). Keunikan rumah Baba Nyonya di George Town serta budayanya. Diakses pada 9 Januari 2017 dari http://shegroup44.blogspot.my/2012/11/keunikkan-rekabentuk-rumah-baba-nyonya.html

13. PYZAM (2010). Adat dan budaya etnik di Malaysia. Diakses pada 9 Januari 2017 dari http://bmpengurusan2010.blogspot.my/2010/09/baba-dan-nyonya.html

14. Sinar Harian (2014). Kasut manik Umbai Melaka. Diakses pada 9 Januari 2017 dari http://www.sinarharian.com.my/rencana/kasut-manik-umbai-melaka-1.254903

15. Transez (2016). Peranakan. Diakses pada 9 Januari 2017 dari https://transez.wordpress.com/2012/07/22/peranakan/

16. Utusan Online (2008). Keunikan budaya Baba Nyonya. Diakses pada 9 Januari 2017 dari http://ww1.utusan.com.my/utusan/info.asp? $=2008 \& d t=0327 \& s e c=$ Selatan\&pg=ws 01.htm

17. Utusan Online (2010). Keunikan kasut bermanik. Diakses pada 9 Januari 2017 dari http://ww1.utusan.com.my/utusan/info.asp? $=2010 \& \mathrm{dt}=0522 \& p u b=$ Utusan_Malaysia\&sec $=$ Selatan\&pg $=\mathrm{W}$ s $01 . h t m$

18. Worden, N. (2003). National identity and heritage tourism in Melaka. Indonesia and the Malay world, 31(89), 31-43.

\section{Interview}

May Lim Siew Seng, 66 Lebuh Acheh, Pulau Pinang, 6 November 2016 